\title{
Ovarian Tumours - A Six Year Study From A Teaching Hospital In North-East India.
}

\author{
L. Sushila Devi ${ }^{1}$,Anjelica L. ${ }^{2}$, Nisa Kaiho ${ }^{3}$,L. Ranjit Singh ${ }^{4}$ \\ I(Associate Professor, Dept. Of Pathology, Jawaharlal Nehru Institute Of Medical Sciences, Imphal, Manipur, India) \\ ${ }_{2}^{2}$ (P.G. Trainee, Dept. Of Surgery, Regional Institute Of Medical Sciences, Imphal, Manipur, India) \\ ${ }_{3}^{3}$ (Tutor, Dept. Of Pathology, Jawaharlal Nehru Institute Of Medical Sciences, Imphal, Manipur, India) ${ }^{4}$ (Professor, \\ Dept. Of Obstetrics And Gynaecology, Regional Institute Of Medical Sciences, Imphal, Manipur, \\ India)
}

\begin{abstract}
Ovarian tumours are responsible for significant morbidity and mortality in women. Relative frequency of these tumours show geographical variations and many of them are symptomless till they are clinically advanced. The present cross-sectional study focuses on various histological patterns of ovarian tumours, their distribution in different age groups and to compare it with other studies in patients admitted at a teaching hospital in Imphal. The benign, borderline and malignant tumours were $81.5 \%, 6.5 \%$ and $12.0 \%$ respectively. Surface epithelial tumours account for majority of the cases (65.3\%), followed by germ cell tumours (33.1\%). Serous cystadenoma was the most common tumour (43.6\%) and mature cystic teratoma (37.6\%) was the second most common type. Among the malignant neoplasms, mucinous cystadenocarcinoma emerges as the most common type (33.3\%). Bilaterality was seen in $4.8 \%$. Of all ovarian tumours, benign tumours outnumbered malignant ones in our study and were seen more commonly in younger patients except for immature teratomas which were seen in patients $\leq 20$ years. Early diagnosis and treatment is of vital importance especially in the malignant types to lower the case fatality.
\end{abstract}

Keywords: Histologic types, Matureteratoma, Ovarian tumours, Serous cystadenoma.

\section{Introduction}

There is an increase in the incidence of cancers as the human longevity increases. Ovarian cancer is the 3rd most common cancer amongst female genital tract cancers and ranks only below carcinoma of the cervix and the endometrium. It ranks 4th in cancer death among women.[1] Ovarian cancer is the 7th most common cancer in women worldwide with 2,39,000 new cases diagnosed in 2012.[2] In Manipur, according to the population based cancer registry (2014), it is the 6th most common cancer among females. Many of these neoplasms are undetectable in the early stage because of its intra-abdominal location and frequently asymptomatic till they are in a clinically advanced stage. Unlike cervical cancer, precursor lesions are largely unknown and screening methods like bimanual pelvic examination, estimation of CA-125, ultrasonography etc. lack sensitivity and specificity. Geographical variations exist in the relative frequency of various ovarian tumours. Indian cancer registry data project ovary as an important site of cancer in women comprising upto $8.7 \%$ of cancers.[3] Determination of the specific histopathological pattern is important for diagnosis, management and prognosis.

\section{Materials And Methods}

This is a cross-sectional study done in the department of Pathology, Jawaharlal Nehru Institute Of Medical Sciences (JNIMS), Imphal, from January 2009 to December 2014. All the specimens of ovarian tumours received for histopathological examination (HPE) were included in this study. All non-neoplastic lesions of the ovary were excluded. Data including age, clinical presentation, laterality and related history were obtained from the histopathological forms and medical record section. Histopathological findings of each case were studied. Hematoxylin and eosin (H\&E) stain was used for each case and special stains (PAS, mucicarmine and reticulin) were also used where appropriate.

\section{Aims And Objectives}

To study the various morphological and histological types of ovarian tumours and also to analyse the distribution of these tumours in different age groups, laterality and their incidence at JNIMS.

\section{Results}

A total of 124 specimens of ovarian tumours were obtained during the study period. Out of these, surface epithelial tumours contributed the bulk of the cases $(65.3 \%)$, followed by germ cell tumours (33.1\%), sex-cord stromal tumours $(0.8 \%)$ and metastatic tumours $(0.8 \%)$. Six patients $(4.8 \%)$ had bilateral tumours consisting of benign $(66.7 \%)$ 
and malignant (33.3\%) cases. Mixed epithelial and mixed epithelial and germ cell tumours comprised $16.7 \%$ each of the bilateral tumours.

Total number of benign, borderline and malignant ovarian tumours were $81.5 \%, 6.5 \%$ and $12 \%$ respectively. Among the benign tumours, serous cystadenoma was the commonest type (43.6\%) [Table-1]. Borderline and malignant tumours were more common in mucinous tumours [Table-2\&3]. Benign tumours were more common in patients <40 years of age whereas majority of the malignant tumours occurred in patients $>40$ years, except immature teratoma cases which occurred $\leq 20$ years of age. Maximum number of borderline tumours occurred in 31-40 years age group. Benign tumours were mostly cystic, $(96.04 \%)$ and only $3.96 \%$ consisting of benign Brenner tumour and fibroma were solid. Reticulin stain highlighted the investment of individual tumour cells by fibrils. The borderline and malignant tumours show a heterogenous proportion of both solid and cystic components. Benign cystic teratoma (mature teratoma) contain sebum-like material and hair on cut section and showed mostly ectodermal elements like squamous epithelium and subepithelialadnexae like hair follicles.

\section{Discussion}

Ovarian tumours constitute an important group of neoplasia in women. Wide geographic variation in the incidence rate of ovarian tumours exists with higher rate in the industrialized countries.In the present study, benign, borderline and malignant tumours comprise $81.5 \%, 6.5 \%$ and $12 \%$ respectively. Pillai $\mathrm{G}$ et al [4] and Gupta et al [5] reported similar findings but Ahmed et al [6] reported a lower incidence of benign and borderline but a much higher incidence of malignant tumours. Surface epithelial tumours account for $65.3 \%$ of all tumours similar to the findings of other workers [5][7][8].

5.1. Benign tumours: In the present study, $60.4 \%$ of the benign tumoursbelongs to the surface epithelial tumours. Of the 101 benign tumours, 6 cases occurredin $\leq 20$ years of age and 8 cases were seen in $>60$ years of age. Tumourbilaterality was seen in 6 cases.

5.1.1. Serous cystadenoma: It emerges as the commonest benign ovarian tumour in our study and maximum number of cases are seen in the $4^{\text {th }}$ and $5^{\text {th }}$ decades. Our findings correlates with other authors [7][9], but Ahmed et al [6] reported mucinous cystadenoma as the most common benign tumour. A case of serous cystadenofibroma was included in the present study which multiloculated cyst as well as focal gray-white solid areas..

5.1.2. Brenner tumour: 2 cases of benign Brenner tumour are observed in the present study.Grossly, it show focal yellow areas and small cystic areas. Microscopically, it consists of a fibrous stroma, resembling that of normal ovary, is marked by sharply demarcated nests of epithelial cells that resemble the epithelium of urinary tract. (Figure-1) A case of bilateral benign Brenner tumour and bilateral serous cystadenoma was observed in our study. It comprises $1.6 \%$ of the cases in our study which were seen in post-menopausal women and it correlates with the findings of Tulon Borah et al.[10]

5.1.3. Fibroma: These tumours are rare in women < 20years of age and occur usually in women $>30$ years of age. They can be bilateral in about $5 \%$ of the cases. Only $1 \%$ of fibromas can present with Meig'ssyndrome( triad of ovarian fibroma, ascites and pleural effusion). Our findings of an incidence of $1.98 \%$ of fibroma is also comparable to the studies done by Pillai G et al [4] and PurtiAgarwal et al.[11]

5.1.4. Germ cell tumours: These comprise $33.1 \%$ of all ovarian tumours in our study, out of which $92.7 \%$ are mature teratoma. Our findings are higher to that of other workers. [4][12]Mature cystic teratoma emerges as the 2nd most common benign tumour in our study. (Figure-2)

5.2. Borderline tumours: Mucinous borderline and serous borderline tumours (Figure-3) comprise $50 \%$ and $37.5 \%$ of all borderline tumours in our study which is similar to that of Li et al [13]. However, Priya et al [14] observed serous borderline tumours more common than the mucinous borderline tumours. A case of serous cystadenofibroma of borderline type was also seen in our study. Serous cystadenofibroma and serous cystadenofibroma of borderline type comprise $0.81 \%$ of all ovarian tumours in the present study which is comparable to other studies [10][15].

5.3. Malignant tumours: Fifteen malignant tumoursare seen in our study and all are unilateral tumours. Malignant tumours of surface epithelial origin comprises $73.3 \%$ of all malignant tumours.

5.3.1. Mucinous cysadenocarcinoma. Out of the 5 mucinous systadenocarcinomas seen in the present study, bilaterality is seen in one case.Mucinoustumours tend to be larger with areas of cystic as well as solid areas.Pseudomyxomaperitonei which was histerically thought to be associated with many cases of primary ovarian mucinous tumouris now thought to be of extraovarian primary mucinous tumour.

Higher incidence of borderline and malignant mucinous tumours in the present study are comparable to that of Atif Ali Hashmi et al [16] whereas Jha et al [17] and Mankar D.V. et al [12] reported serous cystadenocarcinoma as the commonest malignant neoplasm in their studies. Swamy et al [18] and Yasmin et al [19] found granulosa cell tumour and endometrial carcinoma as the commonest malignant tumour in their respective studies.

5.3.2. Serous cystadenocarcinoma. A significant proportion of both serous borderline and malignant serous tumours involve the surface of the ovary. Ovarian serous tumours have the propensity to spread to the peritoneal surfaces and omentum. Such findings are found in 3 cases in our study psammoma bodies are also noted in 2 cases. 
5.3.3. Malignant germ cell tumour. In the present study, immature teratoma comprised $1.61 \%$ of all ovarian tumours and $13.33 \%$ of all ovarian cancers, whereas that of choriocarcinoma is $0.81 \%$ and $6.7 \%$ respectively. Topuz S et al [20] reported lower incidence of both tumour types.Choriocarcinomas are rare ovarian tumours and its incidence in our study is comparable to the findings of other workers [19][21].

5.3.4. Clear cell carcinoma is another rare type of ovarian malignant tumour (Fig.4) and has the same incidence rate as that of immature teratoma in the present study. Bilaterality can be seen in $<10 \%$ of the cases.Tumour cells growing in short papillae with hyalinised cores lined by clear cells with focal cytoplasmic PAS positive with diastase resistant hyalinised globules ( Figure- )Our findings correlate with other studies [21][22] but PurtiAgarwal et al [11] reported lower incidence in their studies.

5.3.5. Our findings of metastatic tumours(Krukenbergtumour) constituting $0.81 \%$ of all ovarian tumours and $6.67 \%$ of all ovarian cancers are comparable with that of other authors [11][12][23] but higher incidence was reported by Mukwana et al [22] and Mankar D.V. et al [12].

5.4. Tumourbilaterality: Tumourbilaterality was observed in $4.8 \%$ of the cases which is lower to the finding of other workers [4][18][21][24]. Two cases are malignant tumours. A case of bilateral benign Brenner tumour associated with bilateral serous cystadenoma was included in our study. Such tumours were also highlighted by Pschera $\mathrm{H}$ et al [25].

5.5. Age Incidence: Ovarian neoplasms occur in the age range of 11-76 years with the maximum incidence in 31-50 year age group. Pillai $G$ et al [4] reported the peak incidence of ovarian tumours in the 3rd and 4th decades. Benign tumours are more common in patients $<40$ years of age except immature teratoma, whereas maximum malignant tumours occur after 40 years of age. Maximum number of borderline tumours occur in the 4 th decade of life. The mean age at diagnosis for benign, borderline and malignant tumours in our study are $36.65 \pm 13.81,44.63 \pm 11.12$ and $40.93 \pm 15.03$ respectively. Our findings for borderline and malignant tumours are comparable to that of a Brazilian study[26] however the mean age for benign tumoursare higher in their studies. The mean age of borderline tumours in a study by Wang et al [27] in Singapore is 38 years.

\section{Vl. Conclusion}

Ovarian tumours are one of the common ailments affecting women with wide geographic variation in the incidence.Ovarian cancers account for a disproportionate number of deaths from cancer of the female genital tract which are largely related to lack of proper screening method and late diagnosis. Health education, passive surveillance, development of a better screening method etc. will be of prime importance in detecting ovarian malignancies at an early stage. For clear understanding of the disease pattern in this north-eastern part of India, a study with a larger sample size over a longer duration of study would be needed.

\section{References}

[1]. Jemal A, Siegel R, Xu J, Ward E. Cancer statistics, 2010. CA Cancer J Clin.2010;60:277-300.

[2]. World Cancer Research Fund. Available from: http//www.werf.org/int/cancer facts-figures/data-specific-cancers/ovarian cancer statistics.

[3]. Murthy NS, Shalini S, Suman G, Pruthvish S, Mathew A. Changing trends in incidence of ovarian cancer - the Indian Scenario. Asian Pac J Cancer Prev2009;10:1025-30.

[4]. Pilli G, Suneeta KP, Dhaded AV, Yenni VV. Ovarian tumours: a study of 282 cases. Journal of Indian Medical Association 2002;100:420-4.

[5]. Gupta N, Bisht D, Agarwal AK, Sharma VK. Retrospective and prospective study of ovarian tumours and tumour-like lesions. Indian J PatholMicrobiol 2007;50:525-7.

[6]. Ahmed Z, Kayani N, Hasan SH, Muzaffar S, Gill MS. Histological pattern of ovarian neoplasm. J Pak Med Assoc 2000;50:416-9.

[7]. Shah S, Hishikar VA. Incidence and management of ovarian tumours. Bombay Hospital J 2008;50:30-3.

[8]. Zaman S, Majid S, Hussain M, Chughtai O, Mahboob J, Chughtai S. A retrospective study of ovarian tumours and tumour-like lesions. J Ayub Med Coll Abbottabad 2010;22:104-8.

[9]. Lubna Khan, Anita Arora, AshaAgarwal, ChayanikaPantola, Sanjay Kala, Rahul K. Rathi. Role of immunohistochemistry in ovarian tumours. Journal of evolution of medical and dental sciences 2014;3(11):2814-8.

[10]. Cho SM, Byun JY, Rha SE et al. CT and MRI findings of cystadenofibroma of the ovary. EurRadiol. 2004;14(5):798-804.

[11]. PurtiAgrawal, Deepak GangadharKulkarni, PreetiRihalChakraborti, SapnaChourasia, Mona Dixit, Kapil Gupta. Clinicopathological spectrum of ovarian tumours: A 5 year experience in a tertiary health care centre. Journal of basic and clinical reproductive sciences. July-Dec 2015;4(2):90-6.

[12]. Mankar DV, Jain GK. Histological profile of ovarian tumours: A twelve year institutional experience. Muller J MediSci Res 2013;6(2):107111.

[13]. Li Y, Cui H, Shen DH, Zhao Y, Wei LH, Quian HN. Clinical and pathological features of borderline ovarian tumours.Zhonhua Fu Chan KeZaZhi2003;38:81-4.

[14]. Priya C, Kumar S, Kumar L. Borderline ovarian tumour: An update. Indian J Med PaediatrOncol 2008;29:19-27.

[15]. Byun JY. MR imaging findings of ovarian cystadenoma: clues for making the differential diagnosis from ovarian malignancy. Korean J Radiol. 2006;7(3):153-60.

[16]. Mankar DV, Jain GK. Histological profile of ovarian tumours: A twelve year institutional experience. Muller J MediSci Res 2013;6(2):107111.

[17]. Atif Ali Hashmi, ZubaidaFidaHussain, Aneel Roy Bhagwani, Muhammad MuzzammilEdhi, Naveen Faridi, Syed Danish Hussain. Clinicopathologic features of ovarian neoplasms with emphasis on borderline ovarian tumours: an institutional prespective. BMC Research Notes 2016;9:205. 
[18]. Jha R, Karki S. Histological pattern of ovarian tumours and their age distribution. Nepal Med Coll J 2008;10:81-5.

[19]. Swamy GG, Satyanarayan N. Clinicopathological analysis of ovarian tumours - a study on five year sample. Nepal Med Coll J 2010;12:221 3 .

[20]. Yasmin S, Yasmin A, Asif M. Clinicopathological pattern of ovarian tumours in Peshawar region. J Ayub Med Coll Abbottabad Tupuz S, Iylbzkurt AC, Akhan SE, Keskin N, Yavuz E, Salihoglu Y et al. Malignant germ cell tumours of the ovary: A review of 41 cases and risk factor for recurrence. Euor J GynaecolOncol2008;29:635-7.

[21]. RanjanaBanyopadhyay, Santosh Kumar Mondal, Palash Kumar Mondal, Dipanwita Ray Nag, SuprioRoychowdhury, Swapan Kumar Sinha. Histologic pattern, bilaterality and clinical evaluation of 957 ovarian neoplasms: A ten year study in a tertiary hospital of eastern India. Journal of Cancer Research and therapeutics 2011;7(4):433-7.

[22]. Mokwana HH, MaruAM, Lakum NR, Agnihotri AS, Trivedi NJ, Joshi JR. The relative frequency and histopathological pattern of ovarian masses - 11 year study at tertiary care centre. Int J Med Sci Public Health 2014;3:81-4.

[23]. Zaloudek C: tumours of the ovary. Diagnostic Histopathology of tumour. Christopher DM, Fletcher DM, Fletcher Churchill Livingstone. (Philadelphia USA, 3rd edition,2007)Vol 1, 567-627.

[24]. Annapurna Parvatala, Ragidi Ramesh Babu, Natta Bharat Rao, K Narasimhulu. Study of ovarian neoplastic lesions. IOSR Journal of Dental and Medical Sciences July 2016;15(7):32-8.

[25]. Pschera H, Wikstrom B. Extra ovarian Brenner tumour co-existing with serous cystadenoma: a case report. GynecolObstet Invest 1991;31:185-7.

[26]. Marcela F Paes, Renata D Daltoe, Klesia P Madeira, Lucas CD Rezende, Gabriela M Sirtoli, Alice L Herlinger et al. A retrospective analysis of clinicopathological and prognostic characteristics of ovarian tumours in the state of Espirito Santo, Brazil.Paes et al Journal of ovarian research 2011;4:14.

[27]. Wang HF, Low JJ, Chua Y, Busmanis I, Tay EH, Ho TH. Ovarian tumours of borderline malignancy: a review of 247 patients from 1991 to 2004. Int J Gynecol Cancer 2007;17:342-9.

Table - 1 Distribution Of Benign Tumours In Different Age Groups

\begin{tabular}{|c|c|c|c|c|c|c|c|c|}
\hline \multirow{2}{*}{$\begin{array}{c}\text { Sl. } \\
\text { No. }\end{array}$} & $\begin{array}{c}\text { Type Of Benign } \\
\text { Tumours }\end{array}$ & $\begin{array}{c}\square \mathbf{2 0} \\
\text { Yrs }\end{array}$ & $\begin{array}{c}\mathbf{2 1 - 3 0} \\
\text { Yrs }\end{array}$ & $\begin{array}{c}\mathbf{3 1 - 4 0} \\
\text { Yrs }\end{array}$ & $\begin{array}{c}41-50 \\
\text { Yrs }\end{array}$ & $\begin{array}{c}\mathbf{5 1 - 6 0} \\
\text { Yrs }\end{array}$ & $\begin{array}{c}>60 \\
\text { Yrs }\end{array}$ & $\begin{array}{c}\text { Total No. } \\
\text { Of Each } \\
\text { Tumour } \\
\text { Type }\end{array}$ \\
\hline 1. & $\begin{array}{c}\text { Serous } \\
\text { Cystadenoma }\end{array}$ & 0 & 8 & 12 & 12 & 6 & 6 & 44 \\
\hline 2. & Mature Teratoma & 4 & 18 & 8 & 8 & 0 & 0 & 38 \\
\hline 3. & $\begin{array}{c}\text { Mucinous } \\
\text { Cystadenoma }\end{array}$ & 2 & 8 & 1 & 1 & 1 & 1 & 14 \\
\hline 4. & Benign Brenner & 0 & 0 & 0 & 0 & 1 & 1 & 2 \\
\hline 5. & $\begin{array}{c}\text { Serous } \\
\text { Cystadenofibroma }\end{array}$ & 0 & 0 & 1 & 0 & 0 & 0 & 1 \\
\hline 6. & Fibroma & 0 & 0 & 0 & 1 & 1 & 0 & 2 \\
\hline
\end{tabular}

Table - 2 Distribution Of Borderline Tumours In Different Age Groups

\begin{tabular}{|c|c|c|c|c|c|c|c|}
\hline \multirow{2}{*}{ S1. No. } & $\begin{array}{c}\text { Type Of } \\
\text { Borderline } \\
\text { Tumours }\end{array}$ & $\square 30$ Yrs & $31-40$ Yrs & $41-50$ Yrs & $51-60$ Yrs & $>60$ Yrs & $\begin{array}{c}\text { Total No. } \\
\text { Of Each } \\
\text { Tumour } \\
\text { Type }\end{array}$ \\
\cline { 3 - 7 } & $\begin{array}{c}\text { Mucinous } \\
\text { Tumours }\end{array}$ & 0 & 1 & 0 & 1 & 1 & 4 \\
\hline 2. & Serous Tumours & 0 & 3 & 0 & 1 & 0 & 3 \\
\hline 3. & $\begin{array}{c}\text { Serous } \\
\text { Cystadenofibroma }\end{array}$ & 0 & 1 & 0 & 0 & 0 & 1 \\
\hline
\end{tabular}

Table - 3 Distribution Of Malignant Tumours In Different Age Groups

\begin{tabular}{|c|c|c|c|c|c|c|c|c|}
\hline \multirow[b]{2}{*}{ Sl. No. } & \multirow[b]{2}{*}{$\begin{array}{c}\text { Type of malignant } \\
\text { tumours }\end{array}$} & \multicolumn{6}{|c|}{ Age groups } & \multirow{2}{*}{$\begin{array}{c}\text { Total } \\
\text { no. of } \\
\text { each } \\
\text { tumour } \\
\text { type }\end{array}$} \\
\hline & & $\begin{array}{l}\square 20 \\
\text { yrs }\end{array}$ & $\begin{array}{c}21-30 \\
\text { yrs }\end{array}$ & $\begin{array}{c}31-40 \\
\text { yrs }\end{array}$ & $\begin{array}{c}\text { 41-50 } \\
\text { yrs }\end{array}$ & $\begin{array}{l}51-60 \\
\text { yrs }\end{array}$ & $>60 \mathrm{yrs}$ & \\
\hline 1. & $\begin{array}{c}\text { Mucinous } \\
\text { cystadenocarcinoma }\end{array}$ & $\mathbf{0}$ & $\mathbf{0}$ & 1 & 2 & 1 & 1 & 5 \\
\hline 2. & $\begin{array}{c}\text { Serous } \\
\text { cystadenocarcinoma }\end{array}$ & $\mathbf{0}$ & $\mathbf{0}$ & 1 & 3 & $\mathbf{0}$ & $\mathbf{0}$ & 4 \\
\hline 3. & $\begin{array}{l}\text { Clear cell } \\
\text { carcinoma }\end{array}$ & 0 & $\mathbf{0}$ & 1 & 1 & $\mathbf{0}$ & $\mathbf{0}$ & 2 \\
\hline 4. & Immature teratoma & 2 & $\mathbf{0}$ & $\mathbf{0}$ & $\mathbf{0}$ & $\mathbf{0}$ & $\mathbf{0}$ & 2 \\
\hline 5. & Choriocarcinoma & $\mathbf{0}$ & 1 & $\mathbf{0}$ & $\mathbf{0}$ & $\mathbf{0}$ & $\mathbf{0}$ & 1 \\
\hline 6. & $\begin{array}{c}\text { Metastatic } \\
\text { adenocarcinoma }\end{array}$ & $\mathbf{0}$ & 1 & $\mathbf{0}$ & $\mathbf{0}$ & $\mathbf{0}$ & $\mathbf{0}$ & 1 \\
\hline
\end{tabular}


Ovarian Tumours - A Six Year Study From A Teaching Hospital In North-East India.

Table - 4 Distribution Of Bilateral Tumours In Different Age Groups

\begin{tabular}{|c|c|c|c|c|c|c|c|c|}
\hline \multirow{2}{*}{$\begin{array}{l}\text { Sl. } \\
\text { No. }\end{array}$} & \multirow{2}{*}{ Type of tumours } & \multicolumn{6}{|c|}{ Age groups } & $\begin{array}{c}\text { Total no. of } \\
\text { bilateral }\end{array}$ \\
\hline & & $\square 20$ yrs & $\begin{array}{c}21-30 \\
\text { yrs }\end{array}$ & $\begin{array}{c}31-40 \\
\text { yrs }\end{array}$ & $\begin{array}{c}41-50 \\
\text { yrs }\end{array}$ & $\begin{array}{c}51-60 \\
\text { yrs }\end{array}$ & $\begin{array}{l}>60 \\
\text { yrs }\end{array}$ & \multirow{7}{*}{6} \\
\hline 1. & $\begin{array}{c}\text { Bilateral Serous } \\
\text { cystadenoma }\end{array}$ & $\mathbf{0}$ & $\mathbf{0}$ & 0 & $\mathbf{0}$ & $\mathbf{0}$ & 1 & \\
\hline 2. & $\begin{array}{c}\text { Bilateral Mature } \\
\text { teratoma }\end{array}$ & $\mathbf{0}$ & $\mathbf{0}$ & 1 & $\mathbf{0}$ & $\mathbf{0}$ & $\mathbf{0}$ & \\
\hline 3. & $\begin{array}{l}\text { Bilateral Mucinous } \\
\text { cystadenocarcinoma }\end{array}$ & $\mathbf{0}$ & $\mathbf{0}$ & $\mathbf{0}$ & $\mathbf{0}$ & 1 & $\mathbf{0}$ & \\
\hline 4. & $\begin{array}{l}\text { Serous cystadenoma } \\
\text { (left ovary) and } \\
\text { Mature teratoma (rt } \\
\text { ovary) }\end{array}$ & $\mathbf{0}$ & 1 & $\mathbf{0}$ & $\mathbf{0}$ & $\mathbf{0}$ & $\mathbf{0}$ & \\
\hline 5. & $\begin{array}{c}\text { Bilateral Brenner } \\
\text { tumour and Serous } \\
\text { cystadenoma }\end{array}$ & $\mathbf{0}$ & $\mathbf{0}$ & $\mathbf{0}$ & o & $\mathbf{0}$ & 1 & \\
\hline 6. & $\begin{array}{c}\text { Metastatic } \\
\text { adenocarcinoma }\end{array}$ & $\mathbf{0}$ & 1 & $\mathbf{0}$ & $\mathbf{0}$ & $\mathbf{0}$ & $\mathbf{0}$ & \\
\hline
\end{tabular}

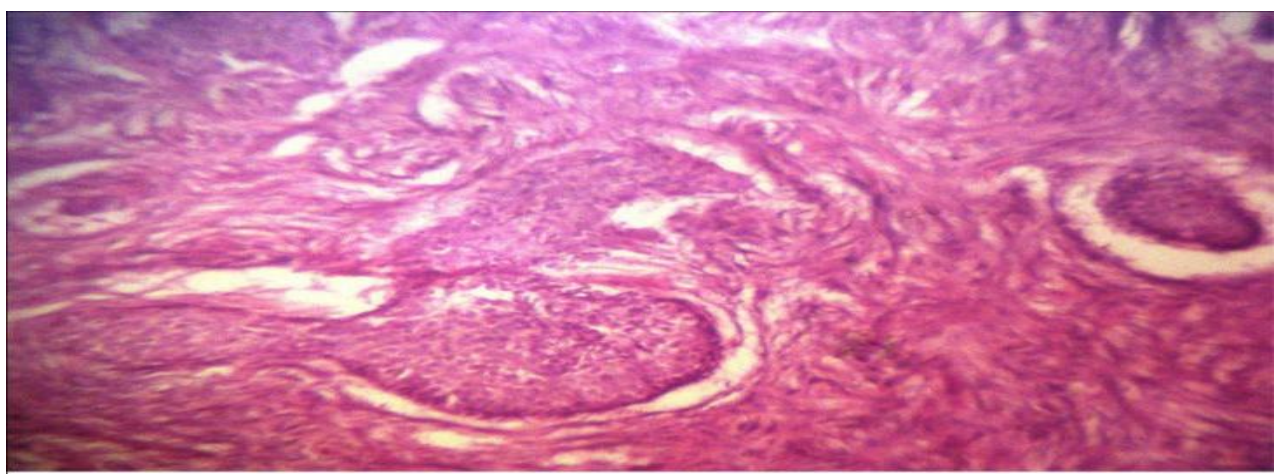

FIG 1.: BENIGN BRENNER TUMOUR - H \& E X 10

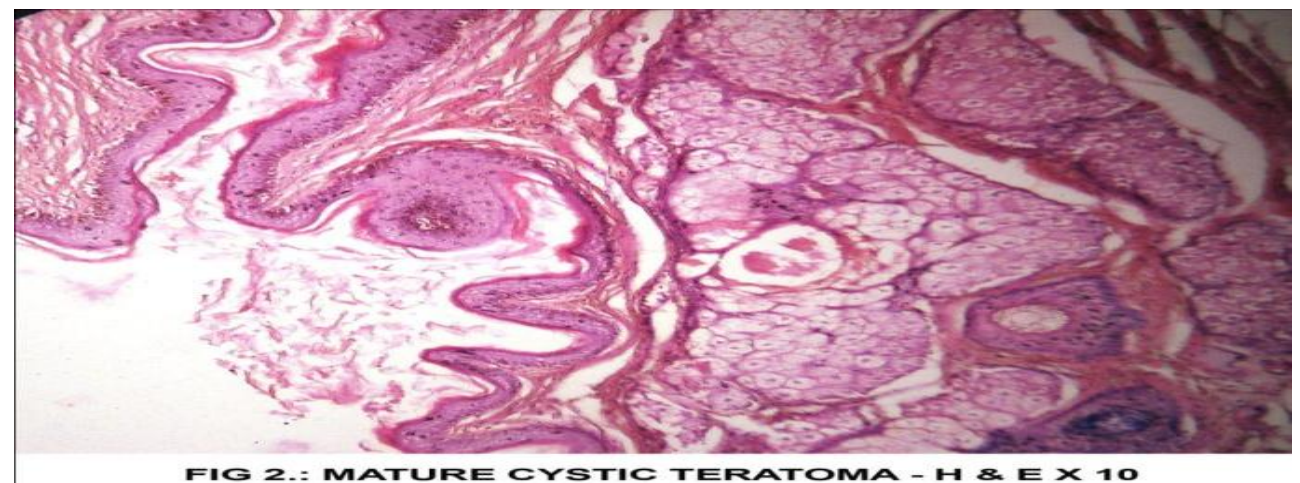

FIG 2.: MATURE CYSTIC TERATOMA - H \& E X 10

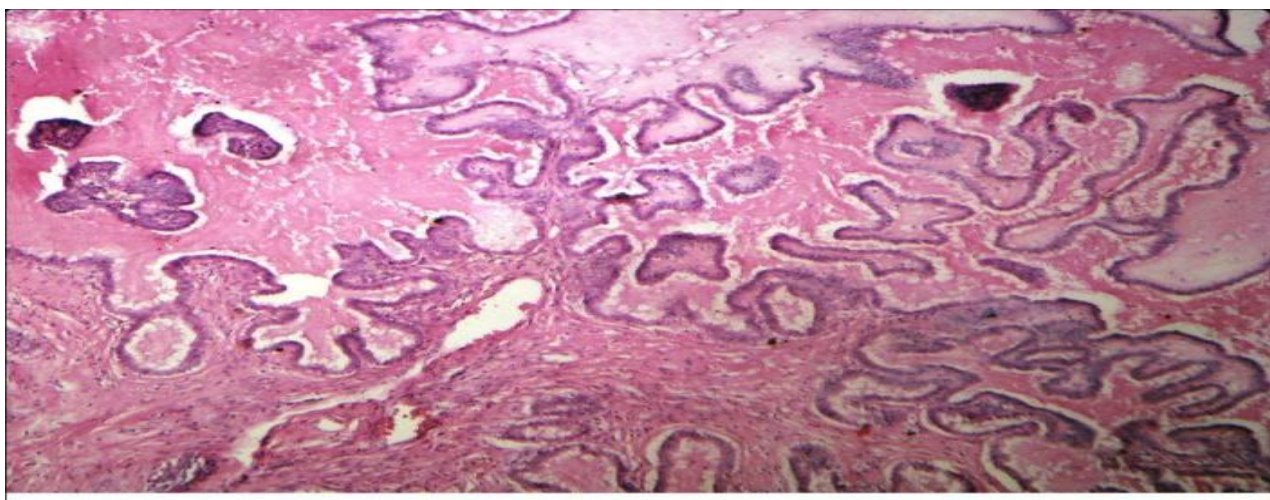

FIG 3.: BORDERLINE SEROUS TUMOUR - H \& E X 10 


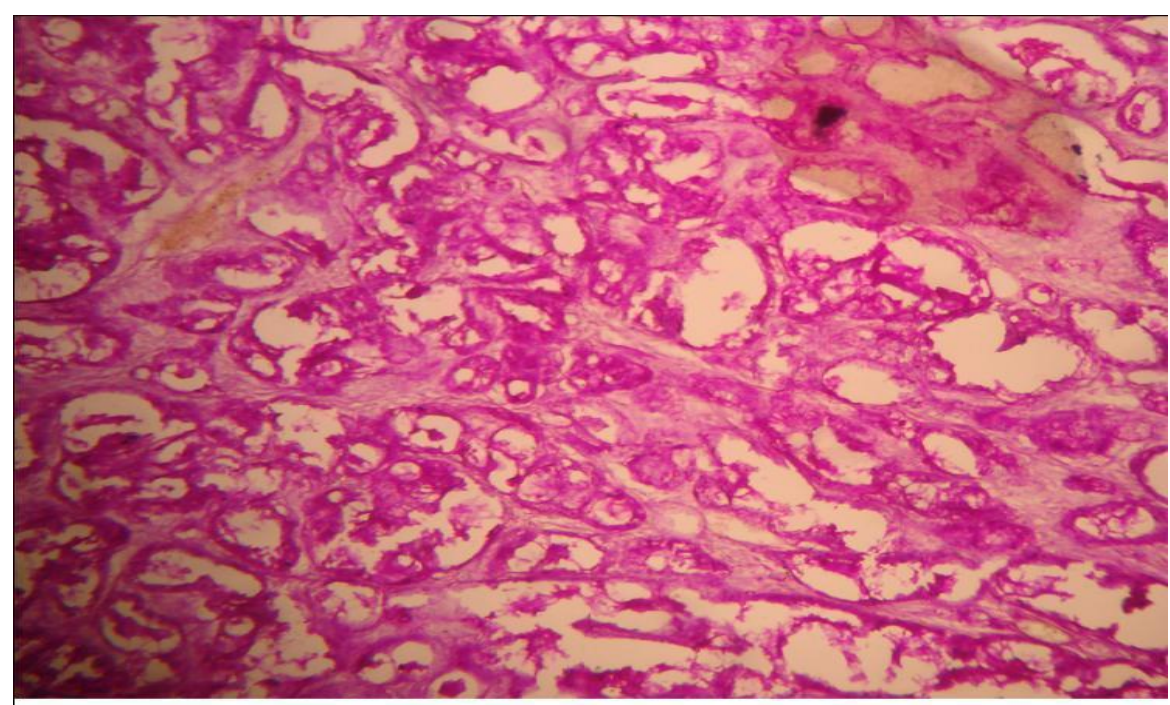

FIG 4.: CLEAR CELL CARCINOMA - PAS X 10 